\title{
Neoliberalism and Homelessness in the Western Canadian Arctic
}

\author{
Michael G. Young \\ Royal Roads University
}

Joshua M. Moses
Haverford College

\section{ABSTRACT}

Homelessness in the Beaufort-Delta represents a significant problem that is underserved by government, market, and nonprofit agencies. Based on research conducted during 2011-2012, this article outlines the breadth and scope of the housing problem and details extant service provision networks for homeless and hard-to-house $(\mathrm{HtH})$ persons with addiction and mental health problems. A critique of neoliberal governance on housing development and social services suggests that significant effort is needed to deal with the problems associated with centralization on the one hand and the isolation associated with Arctic life on the other. The authors conclude by making recommendations for the future role of nonprofit agencies in the Beaufort-Delta through the adoption of a housing first approach.

\section{RÉSUMÉ}

Dans le delta de Beaufort, l'itinérance pose un sérieux défi que négligent les secteurs gouvernemental, commercial et sans but lucratif. Cet article se fonde sur une étude menée en 2011-2012 qui souligne l'envergure du problème de logement et recense les réseaux actuels qui desservent les sans-abris et les personnes difficiles à héberger souffrant de problèmes de dépendance et de santé mentale. II s'ensuit dans cet article la critique d'une politique néolibérale envers la fourniture de logements et de services sociaux. Cette critique suggère qu'un effort important est requis pour surmonter les problèmes reliés à la centralisation des services d'une part et à l'isolement du milieu arctique d'autre part. Pour conclure, l'article propose un rôle futur pour les agences à but non lucratif dans le delta de Beaufort en recommandant à ces dernières une approche qui met l'accent sur les logements avant tout.

\section{Keywords / Mots clés}

Homelessness; Northwest Territories; Neoliberal; Addiction; Nonprofit agencies / Itinérance; Territoires du Nord-Ouest; Néolibéral; Dépendance; Agence à but non lucratif 


\section{Young \& Moses (2013)}

\section{INTRODUCTION}

Since the late 1990s, emergency shelters in urbanizing northern centres such as Inuvik, Northwest Territories (NWT), have reported a steady increase in use, representing a rise in absolute, or "visible," homelessness (Inuvik Interagency Committee, 2003; Yellowknife Homeless Coalition, 2007). Often referred to as chronic or long-term homelessness, this homeless population is typically comprised of chronically ill and/or addicted persons. Under a more comprehensive and socially inclusive definition, homelessness refers to a broader spectrum of people who are considered hard-to-house $(\mathrm{HtH})$ and includes cyclical and temporary homelessness, in addition to chronic homelessness (Echenberg \& Jensen, 2008). Given the geographic and climatic conditions in the Arctic, less visible forms of homelessness, such as "couch surfing" with friends or relatives, are more common in the North than absolute homelessness, even though the latter remains obvious (Inuvik Interagency Committee, 2003, 2006a).

\section{CONTEXT FOR RESEARCH PROJECT}

The NWT covers an area of 1,346,106 square kilometers and has a population of 41,452 . Approximately $46 \%$ of the territorial population $(19,234)$ reside in the capital, Yellowknife, which is the largest urban centre. Although gas and oil exploration are considered important, mining, tourism, and government are the key economic drivers in the territories (Aboriginal Affairs and Northern Development Canada, n.d.). The NWT uses a consensus model of government, meaning that there are no political parties with opposing mandates. Historically, the NWT has relied on transfer payments from the federal government for the majority of territorial operations. Given this funding model, territorial needs often took second place to federal government priorities, particularly regarding the extraction of natural resources. With the onset of devolution, the transfer of governmental authority and responsibility from the federal government to the territories, the NWT is poised to take on more control of territorial governance and the responsibilities associated with this authority. As well, Aboriginal groups in the territory will be responsible for managing resource extraction industries on land under their domain. However, transfer payments and federal influence will continue until the parties involved agree that the new arrangement is stable and complete (Aboriginal Affairs and Northern Development Canada, 2012).

Northern communities frequently have community resources and modes of social organization that mitigate community upheavals related to personal and housing problems. These include informal housing networks and food sharing. However, the ongoing problems associated with poor and overcrowded housing, unemployment, and a long history of government policies designed to erode local resilience have left many communities with frayed networks and limited infrastructure (Morgan, 2010/11). Further, while a great deal of "southern" money has flowed north for high-profile Arctic environmental and geopolitical issues (Gerhardt, Steinberg, Tasch, Fabiano, \& Shields, 2010; Wenzel, 1991), little of this money has been used to address the quotidian pressing realities of problems such as homelessness.

Smaller than Yellowknife, Inuvik has a population estimated at 3,321, of which approximately $65 \%$ are Inuvialuit, Gwich'in, or Metis (Citystats, 2009). There are no official HtH statistics, but interviews with local service providers suggest that, depending on the time of year, more than 30 men and women are $\mathrm{HtH}$. While the city of Yellowknife continues to be the focus of territorial government-led interventions surrounding homelessness, Inuvik tends to be disregarded as a significant recipient of homeless persons from outlying communities and as a hub for northern homelessness. Similarly, the Homelessness Partnering Strategy (HPS), which provides federal funding to designated urban communities and a few rural and Aboriginal communities, includes Yellowknife, but not Inuvik (Employment and Development Services Canada, 2013). Based on the application criteria of the HPS program, which includes the requirement of a community plan

ANSERJ To be notified about new ANSERJ articles, click subscribe / s'inscrire ici. 


\section{Young \& Moses (2013)}

and the ability to match funding (Employment and Development Services Canada, 2013), the town of Inuvik did not qualify for funding. Yet, as the administrative, economic, and governance centre of the Beaufort-Delta region, as well as the most northerly point on the Dempster Highway, Inuvik is a receiving centre for many people who are homeless, or vulnerable to homelessness, and who also suffer from addictions and mental health problems (Christensen, 2012). With the exception of an emergency shelter that can accommodate 16 adults and a women's transitional home that houses up to 10 women and children at a time, services to homeless persons in Inuvik with addictions and mental health problems are limited to relatively scant professional services provided by the Beaufort-Delta Health \& Social Services Authority, Gwich'in Tribal Council, and Inuvialuit Regional Corporation. None of these services are offered on an outreach basis (Inuvik Interagency Committee, 2006b).

Any attempt to understand homelessness in the Arctic must include an appreciation of the social, historical, cultural, and economic contexts within which communities emerge and develop. Abele (2009) argues that the social economy has been largely ignored in what little research does exist on northern development. Yet the impact of large-scale government transformation has a significant and enduring impact on community development. Clearly, the lack of nonprofit organizations in the North generally, and in Inuvik specifically, can be linked to changing governmental priorities, which are tied to social economy and nonprofit development. In the case of the Beaufort-Delta, Inuvik was created in the 1950s with the express intention of being a beacon of Canadian sovereignty in the North. The exploitation of oil and gas came later, circa the 1970s, and with this expansion came boom-and-bust economies and the perks and problems associated with them (Abele, Falvo, \& Hache, 2010; Christensen, 2012).

The federal government is the prime source of funding for nonprofit services; indeed, the federal government is the primary source of income for the majority of residents living in the NWT, either as a source of employment or for social assistance (Christensen, 2011; Laird, 2007). Aside from verbal accounts from research participants of detoxification services once offered at the location of the current emergency shelter, there is no historical evidence of addiction or mental health services leading up to the 1990s in Inuvik. Arguably, the shift to neoliberal governance - manifest in the creation and maintenance of conditions favourable to economic investment as well as the gutting of social services starting in the 1980s-illustrates the direct impact of changes to social policies guiding housing and the surge in homelessness across Canada and other western democracies (Caragata, 2006; Cloke, Milbourne, \& Widdowfield, 2000; Hackworth \& Moriah, 2006).

The growth of the homeless population evidenced in the 1990s coincided with roll-back neoliberal policies identified by Peck and Tickell (2003). Essentially, discrediting or eliminating Keynesian welfare-state policies involves a reduction in state control of resources and regulations, which results in dwindling public services and the reduction of social and labour rights. In addition, the privatization of once state-controlled programs places the distribution and control of services in the hands of the private sector. Thus, public assets are sold and many social programs come to be provided through contracting services with nonprofit organizations (Aguirre, Eick, \& Ellen, 2006).

While a complete accounting of the factors associated with homelessness in this research is not possible, the impact of changing governance models, in this case the shift to roll-back and roll-out neoliberal paradigms, has effectively intensified the housing shortage and obstructed the development of addiction and mental health services. Regarding roll-back policies, a significant impact on housing occurred in the 1990s with the cancellation of federally sponsored social and affordable housing programs (Social Planning and Research Council of BC, 2012). Indeed, Caragata (2006) observes that policy retrenchment, evidenced by the offloading of housing responsibilities from federal and provincial levels of government to municipalities, resulted

ANSERJ To be notified about new ANSERJ articles, click subscribe / s'inscrire ici, 


\section{Young \& Moses (2013)}

in the growth of homelessness in Canada akin to that in the United States. As well, the recent administrative centralization of northern communities, which occurred in the 1950s and '60s (Wenzel, 2008), has not been matched by the development of resources to deal with increased levels of migration.

Organizations such as the Inuvik Interagency Committee do play a role in the organization of services, but the region itself does not have a resource infrastructure capable of dealing with problems of such magnitude as those being experienced in Inuvik and the Beaufort-Delta. In short, the social and economic capital required to address housing, addiction, and mental health problems is not available. In this context, decentralizing and off-loading services, assuming they were available to begin with, has met with disaster. In the aftermath of decentralization, combined with the demise of social and affordable housing in the 1990s, communities are considered fortunate if they can garner a triage response to the problems associated with homelessness. Several years ago, Hall and Reed (1998) suggested that the future did not look promising in this regard; today in Canada we can say it is bleak.

Efforts to secure the best conditions for capital or roll-out neoliberal policies (Aguirre, Eick \& Ellen, 2006) also have negative impacts on society. Within a global context, the drive to maintain a competitive edge in a global marketplace requires the state to endorse policies that promote or provide the infrastructure necessary to educate and maintain a fully participatory workforce (McBride \& McNutt, 2007). Due to a lack of suitable and stable employment opportunities, those unable to participate in such an environment, in this case northern residents and particularly Aboriginal people, are at a further disadvantage and excluded from the labour market. Coupled with the erosion of key public services, such as healthcare and social services resulting from roll-back policies, roll-out neoliberal policies place HtH populations in Inuvik and the Beaufort Delta at an extreme disadvantage.

Linked to boom-and-bust economies, and driven by oil and gas exploration, the rising costs of housing in rural centres such as Inuvik have intensified housing shortages (Inuvik Interagency Committee, 2003, 2006b). Moreover, multiple generations of families often share housing originally designed for single families, which tends to obscure the true nature of the housing shortage (Inuvik Interagency Committee, 2003, 2006b). Coupled with a dearth of services to HtH persons, an observation corroborated by Christensen's (2012) research on northern settlement dynamics, the shift to neoliberal policies constitutes market and government failure in that community needs - i.e., housing, addictions, and mental health-are not being met.

Substantively, the philanthropic element of nonprofit organizations relies heavily on volunteer workers and financial donations. Maintaining continuity in service delivery is challenging enough in times of economic growth, but when nonprofits are faced with funding shortfalls, maintaining services becomes almost impossible. The low wages associated with paid positions and the heavy dependence on volunteers are two factors that leave nonprofit organizations in a state of flux, struggling to survive (Covington, 1994; Enjolras, 2000; Hackworth \& Moriah, 2006; Hall \& Reed, 1998). Added to this, employees are often lured away from their nonprofit positions to government jobs that offer higher pay, more benefits, and long-term stability.

While proving direct causal connection between homelessness, addiction, and mental health problems is difficult, the housing shortage in Inuvik and the Beaufort-Delta is a significant contributor to the problems experienced by homeless and $\mathrm{HtH}$ persons. Aboriginal households are four times more likely to be overcrowded (25\% compared to $7 \%$ ), with remote communities experiencing a higher percentage of overcrowding (First Nations Information Governance Committee, 2006). Research on housing in Nunavut also reveals a significant shortage of housing, with one in seven people living without adequate shelter (Laird, 2007). Similarly, in the NWT, housing shortages range from 33\% in larger communities such as Yellowknife to

ANSERJ To be notified about new ANSERJ articles, click subscribe / s'inscrire ici. 


\section{Young \& Moses (2013)}

over $70 \%$ in more remote communities (Northwest Territories Bureau of Statistics, 2010). Given these data, and the geographical realities of living in the Arctic, the seriousness of homelessness and the lack of services for addicted and mentally ill persons cannot be overstated.

\section{PURPOSE OF THE RESEARCH PROJECT}

The causes of homelessness are numerous and complex. The most commonly cited proximal causes include mental illness, substance abuse, marital breakdown, abusive relationships, transition from institutionalized care, and economic factors such as loss of employment, lack of affordable and/or available housing, and economic restructuring (Echenberg \& Jensen, 2008). These factors apply whether referring to urban or rural homelessness. In the present context, and in most northern communities in Canada, being Aboriginal is also considered a risk factor (Caragata, 2006). To be sure, the long-term effects of colonization evidenced in community and personal trauma will be felt for generations to come (Christensen, 2012; Wenzel, 2008). As well, community groups in Inuvik, such as the Inuvik Interagency Committee, have suggested that the gaps in mental health services and the paucity of effective addictions treatment play a very critical role in generating and perpetuating homelessness among northern men and women (Inuvik Interagency Committee, 2003, 2006a, 2006b; Kronstal, 2010).

Given the overlap, both conceptually and in the research context, the term hard-to-house $(\mathrm{HtH})$ includes homelessness, as both imply a lack of permanent address. Using data collected for a larger project on homelessness in the North, this article explores the experiences of HtH persons, and those working with them, regarding needs and gaps in services that may increase the likelihood of HtH persons finding housing and help improve levels of personal health, wellness, and security. This research adopts a housing first approach as a fundamental means of coping with homelessness. In essence, housing first models prioritize the need to keep people housed. To a certain degree, behaviours that are considered unacceptable in other contexts are tolerated, providing that clients adhere to established codes of conduct (e.g., no violence). Just as important is the need to coordinate the efforts of service providers, particularly in regard to $\mathrm{HtH}$ persons who require ongoing support for addictions and mental health (Atherton \& McNaughton Nicholls, 2008). Research demonstrates that housing first practices are effective in housing adults and, at the same time, are associated with improved levels of health and social functioning (Waegmakers Schiff \& Rook, 2012).

\section{METHODOLOGY}

This research is premised on the understanding that supportive resources for housing, substance abuse, and mental health needs, whether supplied by government or nonprofit agencies, are dependent on cultural, economic, and geographical context. Based on the rationale that it contributes to scientific knowledge while at the same time producing social change for stakeholders, particularly research participants (O'Leary, 2004), a community-based research design (Creswell, 2006) was chosen for this project. Community-based research has become the expected approach for research with Aboriginal communities in Canada, especially in the North (National Aboriginal Health Organization, 2005; Ryan \& Robinson, 1996). This method of research parallels in many ways the tenets of Aboriginal methodology (Tuhiwai Smith, 1999) and demands that the research enterprise be adapted "to the culture and context of the participants" (Kelly, Mock, \& Tandon, 2001, p. 348). In addition, this approach includes the pursuit of local research needs and an agenda for motivating social change (Pain, 2003).

The community-based research approach used in this project employed mixed methods, involving all stakeholders in the research project. Informal discussions with community collaborators, including the Inuvik Interagency Committee and its members, were used to identify research needs or concerns and to lay the

ANSERJ To be notified about new ANSERJ articles, click subscribe / s'inscrire ici. 


\section{Young \& Moses (2013)}

groundwork for the project. Information on the breadth and scope of the problem was gathered through focus groups and one-to-one interviews with service providers and community agencies/members dealing with $\mathrm{HtH}$ persons (e.g., Aboriginal groups and health providers). A total of $17 \mathrm{HtH}$ persons were recruited from the Inuvik Emergency Shelter and paid a \$50 honorarium for completing their part in the research.

The needs of $\mathrm{HtH}$ persons and the gaps in services were determined through the use of focus groups and a survey instrument that measured individuals' quality of life; see Quality of Life for Homeless and Hard-toHouse Individuals (QoLHHI) Inventory (Hubley, Russell, Gadermann, \& Palepu, 2009). ${ }^{1}$ This article presents excerpts of the focus group data, as they represent the salient issues relating to gaps in services and the potential role of nonprofit agencies in the community. The data sources include $\mathrm{HtH}$ persons themselves and various professional and volunteer service providers. For clarity, the service provider data is limited to focus group information and, as such, does not include individual information or organizational profiles other than reference to participants' relationship to their roles with $\mathrm{HtH}$ persons.

\section{RESEARCH RESULTS}

The results presented here include the demographic characteristics of $\mathrm{HtH}$ persons. These data are followed by the identification of themes emerging from the $\mathrm{HtH}$ and service provider focus groups. As indicated in Table 1, the majority of $\mathrm{HtH}$ participants in the study were male (14), Aboriginal (14), and separated from their wife or common-law partner (14). Although their responsibilities were not specified, the majority of participants (12) had dependants. Three participants had achieved a grade 12 diploma and three had attended college. The majority of participants (12) originated from the NWT, and eight of those from Inuvik proper. Four participants indicated having a mental disability, and four others indicated having a physical disability. At the time of their interviews, eight participants were staying at the Inuvik Emergency Shelter.

\section{Table 1: Demographic characteristics of research participants}

\begin{tabular}{|c|c|c|}
\hline Sex & Place of birth & Dependants \\
\hline$\ldots \ldots 14$ & Inuvik $\ldots \ldots \ldots 8$ & Yes ..........12 \\
\hline Female ........3 & Other NWT $\ldots \ldots 6$ & No $\ldots \ldots \ldots \ldots 5$ \\
\hline Total .........17 & $\begin{array}{r}\text { Out of NWT } \ldots \ldots .3 \\
\text { Total } \ldots \ldots \ldots \ldots . . .17\end{array}$ & Total .........17 \\
\hline Age & & Disability \\
\hline Range 18-74 & Education & Physical \\
\hline Mean 40.83 & $\begin{array}{l}<\text { Grade } 12 \ldots \ldots 11 \\
\text { Grade } 12 \ldots \ldots\end{array}$ & $\begin{array}{l}\text { Mental } \ldots \ldots \ldots{ }^{4} \\
\text { None } \quad \ldots \ldots \ldots \ldots 9\end{array}$ \\
\hline Ethnicity & Some College $\ldots .3$ & Total .........17 \\
\hline Gwich'in $\ldots \ldots .5$ & Total ...........17 & \\
\hline $\begin{array}{l}\text { Inuvialuit } \ldots \ldots \ldots 9 \\
\text { Other } \ldots \ldots \ldots \ldots 3\end{array}$ & Marital status & $\begin{array}{l}\text { Current residence } \\
\quad \text { Shelter } \ldots \ldots \ldots \ldots 8\end{array}$ \\
\hline Total ..........17 & $\begin{array}{c}\text { Married } \ldots \ldots \ldots .3 \\
\text { Separated } \ldots \ldots \ldots 14 \\
\text { Total } \ldots \ldots \ldots \ldots . . .17\end{array}$ & $\begin{array}{c}\text { Relatives } \ldots \ldots \ldots 4 \\
\text { Housed } \ldots \ldots \ldots .2 \\
\text { Street } \ldots \ldots \ldots{ }^{2} \\
\text { Total } \ldots \ldots \ldots \ldots 17\end{array}$ \\
\hline
\end{tabular}




\section{Young \& Moses (2013)}

The themes emerging from the focus groups with service providers and $\mathrm{HtH}$ persons themselves underscored the lack of nonprofit agencies in the community and a shortage of community-based outreach services. The shortage of adequate housing in the community and the absence of transitional housing for HtH persons results in a circular pattern wherein $\mathrm{HtH}$ persons apply for housing, are evicted, and then wait for another chance to be housed. During this cycle, $\mathrm{HtH}$ persons struggle to survive day to day, staying in the shelter when possible, appealing to their friends and family for a place to stay, or causing a disturbance, which leads to their arrest and detention in the RCMP lockup.

\section{Lack of housing}

At the time of the research, services were inadequate, lacking, or incomplete for the $30 \mathrm{HtH}$ persons in Inuvik. The local shelter holds only 16 people and does not accept persons under the influence of alcohol or illicit substances. As a result, the local RCMP lockup has become a de facto shelter, with over 2,500 admissions annually. According to service providers, homeless persons lack access to treatment and training, such as integrated employment and psychosocial/life skills programs that would provide them with opportunities to avoid homelessness. In addition, HtH persons and service providers identified supportive and/or transitional housing as an important step in helping homeless persons acquire the requisite social skills for healthy functioning. At the moment, however, Inuvik and the Beaufort Delta generally lack the help of organized nonprofit agencies. Referring to the lack of nonprofit agencies, a service provider pointed out, "I have a hard time understanding the imbalance between Yellowknife and here. I mean we don't have Salvation Army, we don't have nothing." In dealing with $\mathrm{HtH}$ persons in need of services, an RCMP officer observed that "once the police are called, our directions are to try to find somewhere safe for this person to go, but if there is nowhere then it's jail."

\section{No beds, no nothing}

Many HtH participants described the difficulty in finding housing, particularly that of encountering long waiting lists. In the words of one research participant:

I decided to come up to Inuvik a year ago, and pretty much stay at the shelter all the time because I ... haven't been able to get housing till recently. But prior to that l've been staying at the shelter. But I still am staying at the shelter until I get into my place. But I stayed at the shelter a little while in Whitehorse and that's about it basically. Getting housing, getting on my feet, but you use the shelter when you have to. That's what l've been doing.

Another $\mathrm{HtH}$ participant pointed to the complicated and often punitive nature of the shelter system.

[T]here is an interesting thing that would be interesting to bring up for the record. I'm too poor to stay at the homeless shelter. That's right, more than likely l'm going to get kicked out of [it] November first because I don't have the cash to stay there. In order to stay at the homeless shelter you're required to go to housing [Inuvik Housing Authority, and] if you have any past debt, unless that debt is paid off, then you can't get on the housing list. If you can't get on the housing list, you're kicked out of the homeless shelter.

Whether this participant's perceptions are accurate is not certain, however, his comments echo a common sentiment-housing policies are seen as punitive. Whether or not all participants' perceptions are accurate, the portrayal of policy is only part of what is important here; those in the system have experienced these policies as forcing them into impossible situations. Indeed, the complex nature of the housing system was also observed in the focus group with the Beaufort-Delta Health and Social Services Authority. As another HtH participant commented: 


\section{Young \& Moses (2013)}

[A]nd far too many times l've made the decision that this person actually need[s] some place to stay, and says if they're drunk and they're outside there's a good chance they are going to die. And what's more important: risking this person's life or me getting evicted for the seventh or eighth time [by] my landlord, who says I told you not to let anyone in the house? So that's how I got to be homeless.

Referring to the impact of housing policies on society, an RCMP officer highlights the effects of systemic limited resources:

If at the shelter if there's no drinking allowed either, so if you're envisioning a place like that-no drinking, no drugs-then of course they have to come to us. And they go to the library and hang out during the day, I see a lot of people hanging out there at the library, the NorthMart, they go and have fried chicken and they pass out on the chairs so they can call us and we go. There's nowhere to put them, no one wants to put up with them, but I haven't seen anybody aggressive. I haven't seen much objections from them. They know there are no other options at this point. It would be nice to have another option.

The RCMP expressed frustration over their lockup becoming the de facto shelter. As providing one of the few places where homeless people can get out of the cold and find a place to sleep, the RCMP are in a good position to view how gaps in the service system impact organizations and individuals. Speaking to filling a need where other social agencies should be involved in providing services to HtH persons, an officer said:

It would be nice to have another option. And of course when it comes to mental illness, we know there's issues, we don't know what they are. Most of them aren't diagnosed; tell me if I'm wrong. We're not trained either in mental illnesses, which is kind of sad because we know that most of the clients that we do take care of are seniors, which is really unfortunate. But you know there are some young ones, and I'm sure there's fetal alcohol syndrome that comes into play, but we're not even trained on that either, so we do our best to deal with those people, but there's not much we can do to help. There [are] no other options. I wish there was. Yes, we'll go pick 'em up, we'll remove that person, but can we bring him somewhere safe ... other than in - as sad as it is - it's a cement cell, no beds, no nothing, it's pretty sad to have to do that.

This RCMP officer points to the fundamental problem of inadequate options. Not only are there not enough beds for $\mathrm{HtH}$ people, many of the people the RCMP are forced to shelter require mental health and substance abuse services. Further, the poignant depiction of older people forced to sleep in cement cells gives one a sense of the despondency expressed by this officer and others who were part of the focus group. "You want to help but there's no options whatsoever."

\section{Punitive housing policies}

Both $\mathrm{HtH}$ persons and service providers noted that HtH participants in this study depend on the Inuvik Housing Authority, and all have at one time or another been evicted for being in arrears in rent or for unacceptable conduct. In many cases, eviction is tied to problems with addiction and/or mental health issues. Eviction for housing persons considered by the housing authority as "undesirable" also occurs, as referenced by a previous quote. The following analysis details some of the experiences of HtH persons and the observations and experiences of those who work with them. It is important to point out, however, that 


\section{Young \& Moses (2013)}

participants' perceptions of housing authority policies are necessarily partial representations of complex interactions with multiple sides. Relationships between $\mathrm{HtH}$ persons, housing authorities, and service providers are frequently emotionally charged as a great deal is at stake.

At the time of the focus groups, the cost of housing for unemployed persons on social assistance was nominal, at $\$ 32$ per month (Northwest Territories Housing Corporation, n.d.). Yet many renters are in arrears and are unable to negotiate payment with the housing authority. While eviction for non-payment is not common, being in arrears is often associated with "problem behaviour," such as housing family or friends who are banned from public housing, which does lead to eviction. Once evicted, HtH persons must reapply for housing, which means going on a waiting list. Regarding unacceptable conduct, HtH participants' stories varied as to what led to eviction, but the consequences were dire. As one participant noted, unless the arrears are dealt with, obtaining future housing is difficult: "If you got arrears with Inuvik Housing right now you're denied ... [and] once you get out of housing it's hard to get back into any kind of housing." Another HtH focus group participant went so far as to say, "[L]ke I said, it is hard to get back into it once you get kicked out. They kind of put you on a blacklist ..."

Eviction for unacceptable conduct is linked to causing damage, causing a disturbance, and housing others who have been evicted and banned from properties managed by the housing authority. HtH participants noted that eviction for drinking, noise, and partying was common. Depending on the level of severity, tenants are granted chances before being finally evicted. Yet in one case a HtH participant was evicted for allowing a banned individual to stay at his house during inclement weather. In his words, "[It] was minus 35 and I was in a unit and some people banged on my door and said it's minus 35 and we have no place to go. ... What's more important: risking this person's life or me getting evicted ...?"

\section{Limited treatment opportunities}

Alcohol abuse also figures into the eviction process. While HtH participants frequently recognized that they needed help, they reported having nowhere to turn. Service provider focus group participants confirmed the HtH participants' claim that detoxification services are not available in Inuvik, and that other community support structures are also lacking (e.g., transitional housing and counseling programs). A review of available services supports this conclusion (Beaufort-Delta Health and Social Services Authority, n.d.). One HtH participant suggested that having to leave the shelter, which closed during the day from 10:00 to 18:00, might contribute to more alcohol abuse because $\mathrm{HtH}$ persons had nowhere to go during the day. For other $\mathrm{HtH}$ participants, alcohol and other substance abuse have become both a cause and effect of being homeless-being evicted from housing or being denied entry into the shelter because they are under the influence leads them to "go get drunk."

Regarding substance abuse and treatment, one $\mathrm{HtH}$ participant reflected on his personal experience.

I have a cousin, a bunch of relatives actually that are alcoholics, but when they go to treatment and when they come back and then there's no help ... how can you really make something work when there's no support? You can't expect an alcoholic or an addict to just be able to keep continuing on a path of sobriety without support.

Another HtH participant identified the effects of limited services on health in Inuvik.

I just had an issue though with the hospital and the doctor. Because I have ADHD I've been trying to take certain drugs or medications to help with it, but their side effects are depression ... so I went to the doctor again. ... She didn't know what to prescribe me so 


\section{Young \& Moses (2013)}

she said she would refer me to the psychiatrist, but they failed to actually put my name down and refer me to the psychiatrist. So when I called, like last week to find out when they would be coming, they said, well, he was just here and has already gone. So now I have to wait again.

When discussing the cause and consequence of homelessness, participants from the Beaufort-Delta Health and Social Services Authority made several observations. Mental health problems, particularly depression, were identified as a key issue. One participant claimed that "depression is probably a big one that leads to suicidal ideation." Another health provider participant followed up and commented that the trauma caused by attending residential school was a root problem for many HtH persons.

[W]hen you talk about the mental illnesses, schizophrenia and bipolar, my experience in Inuvik is that there are a lot of people who are homeless because of past trauma and addictions. So the depression is, it would be-not that we can get to where it's coming from because they're in crises-but really potentially related to their current situation and their history of trauma.

Yet services for addicted HtH persons with histories of residential school trauma or mental illness are lacking, which exacerbates the housing situation, as these people are less capable of acceptable pro-social behaviour and the responsibilities associated with maintaining a residence. As one health provider participant noted:

I see a strong correlation for many people who are homeless in terms of addiction and mental health, especially the chronic ... [W] don't have services for detox and for longerterm care, and so most of those chronic homeless people can't go without, so they will find whatever they need to feed that addiction because of their physical health ... so even expecting somebody to just go move into a shelter and stay sober for six days is probably beyond the limits for some people, and so they're going to take off. As soon as the cravings hit, off they go.

\section{DISCUSSION}

The themes emerging from this research highlight the intersection of social and personal problems. There is a clear relationship between addiction and mental health problems and being homeless or HtH. The observations of participants providing services align closely with those of $\mathrm{HtH}$ persons themselves. Institutional support through the Beaufort-Delta Health and Social Services Authority is available, but at best can be considered triage to complex and vexing problems. While the root causes of addictions are not specified, there is a link between the trauma caused by residential school and addiction (Menzies, 2009; Quinn, 2007). Intergenerational trauma, the stripping away of Aboriginal identity through policies of forced assimilation through residential schools, and the transmission of the resulting trauma through successive generations, is an oft-cited explanation for addictions and other problems (Quinn, 2007). Whether intergenerational trauma is a factor in this case is unclear, as is the connection between residential school experiences and mental health. What is clear, however, is that a significant number of HtH persons in Inuvik require significant support to overcome their addictions and to deal with their mental health issues, but this support is not in place.

Considering the systemic shortcomings, and notwithstanding the shortage of housing, the complexity of public housing policies do little to help $\mathrm{HtH}$ persons navigate the processes of finding a place to live. Without community-based services to assist $\mathrm{HtH}$ persons in dealing with addiction and mental health issues, and

ANSERJ To be notified about new ANSERJ articles, click subscribe / s'inscrire ici. 


\section{Young \& Moses (2013)}

given the influence of others who may sabotage their resident status by imposing themselves in houses from which they are banned, the issue of housing may be moot. Research in rural contexts of British Columbia (Canadian Mental Health Association, n.d.) underscores the point that without some kind of personal stability and systemic support structure, the cycle of application for and eviction from housing will continue.

\section{Local problems / Distant causes}

The nature of the territorial governance structure has ensured, until recently -and it remains to be seen how devolving rights to the territory will alter these relationships-that Ottawa will have a strong hand in determining policy. The devolution of governance to the territory will ultimately leave communities more responsible for the people they govern, but these communities have little control over the forces that have negative effects on the population, particularly those already marginalized from the dominant culture. Indeed, the rise and fall of global commodities markets, the need for oil and gas, and the federal resource policy, determined by Ottawa in partnership with oil, gas, and mining companies, are forces intertwined with daily life in Inuvik. That is, local economic conditions are, at least to a large degree, determined by economic policies set by the federal government. Thus, on the one hand, despite the recent devolution of natural resources to territorial control, oil and gas extraction plays a central role in policy decisions. On the other hand, this devolution entrenches a resource hinterland status to the Beaufort-Delta, with little potential for the expansion of services to people in need.

\section{Disposable populations}

While local Aboriginal control of resources has attracted a great deal of optimism, the benefits of resourcedriven economies have been at best uneven (Bell, 2013). On the one hand, there are those lucky enough to have training and to find well-paid positions in either mining or local business who benefit from economic booms. On the other hand, there are those who are left out of these benefits, due to particular life histories and/or structural dynamics that make it very difficult for them to enter into this new economy. Some of these people are survivors of residential schools, others have until fairly recently depended on land-based activities for their survival. The political economy of resource extraction, despite a great deal of optimism and the public relations done by both Aboriginal and non-Aboriginal governments, has done little to address the struggles of homeless persons.

One example of a P3 (public-private partnership) from this research is the Yellowknife Drop-in Center, which is operated by the John Howard Society. Funded by a three-year grant from the resources company Broken Hill Proprietary (BHP Billiton), a storefront in downtown Yellowknife serves as a place where people who are homeless can get off the streets and have a meal. Although it closes at 18:00, the drop-in centre serves as an important meeting place and is well used. The history of this partnership is instructive. In exit interviews with its own employees, Broken Hill Proprietary human resources staff heard complaints about homeless persons in the downtown area (garbage was another complaint). It was this expression of worker frustration with the "homeless problem" that motivated the grant (Bell, 2013). However, as may be obvious, the drop-in centre does little to address the problem of housing and serves only as a stop-gap measure.

The glaring lack of nonprofit involvement in the North is highlighted by this example. Where nonprofits are involved, they are underfunded and ill equipped to handle the volume and complexity of homelessness, particularly when substance abuse and mental illness are added. However, what appears clear from this example is that corporations, in this case mining companies, are willing to become "good citizens" under particular kinds of pressure. While appeals to empathy and justice may not have an impact on corporations, in light of complaints from employees-particularly white-collar employees from the South-corporations will take action, if needed. 


\section{Young \& Moses (2013)}

\section{CONCLUSION}

The untenable situation of homelessness in the North requires coordinated efforts from communities, governments, and nonprofit organizations. Given the benefits derived from resource extraction, industry too has a role to play. This oft-repeated call is made knowing that this research follows the work of others, on the front lines and within government; yet this call needs repeating, given the continued neglect of northern homelessness. As Bell (2013) writes: "Northern rural poverty amidst resource wealth is not simply a problem for those whose lives are shaped by such conditions: it is a problem for Canada itself' (p. 186).

Whether the result of government, market, or philanthropic failure (Salamon, 1987), or a combination of all three, the inability to provide adequate housing and addiction and mental health services, and the absence of nonprofit agencies in Inuvik, is stark considering the need. Not surprisingly, the lack of community-based and nonprofit service provision is considered by the Inuvik Interagency Committee to be a critical gap requiring amelioration. Interestingly, at a time of increased need, with the exception of the aforementioned emergency services and a few activities in local churches, the nonprofit sector is largely invisible in Inuvik. Hall and Reed (1998) have observed that a significant feature of the neoliberal agenda was to offload services that were once considered the domain of government to the private, nonprofit sector. However, adequate resources to carry out the burden of service delivery, let alone increase the number or level of service delivery options, did not accompany the added responsibility associated with this offloading.

In a territory that boasts the highest per capita income in Canada (Wilson, 2009), the problems plaguing Inuvik, and indeed much of the North, are unacceptable. A realistic first step forward is to adopt a housing first approach (Waegmakers Schiff \& Rook, 2012). This approach advances that shelter is essential to address chronic issues such as addictions and mental health. While acceptable behaviour is expected, abstinence from substances is not assumed. Providing adequate support and resources have proven beneficial in terms of improved health and reductions in substance abuse in both urban and rural settings (Waegmakers Schiff \& Rook, 2012). Ironically, the costs of housing first are significantly less than not doing anything, as Canadian taxpayers spend upward of $\$ 6$ billion annually to cover the costs associated with healthcare, criminal justice, social services, and emergency shelters (Laird, 2007). Even more ironic is the fact that nonprofit agencies working in northern communities, such as the Salvation Army's shelter in Whitehorse, face a daily struggle to survive (Laird, 2007).

In addition to market and government failure to meet community needs, we posit that the nonprofit sector has also failed by not acknowledging or acting on the need for housing and addictions and mental health services in the community. However, recognizing nonprofit failure in the northern context is not a criticism of agencies or personnel, but a critique of neoliberal politics and their negative effects on the provision of services of which nonprofit agencies are but a part. In essence, the apparent social engineering aspect of the neoliberal agenda is a poor fit in northern communities. Indeed, whether this agenda benefits other communities, generally, is debatable (Hackworth \& Moriah, 2006; Harvey, 2005; McBride \& McNutt, 2007). Thus we are faced with a political and moral challenge, rather than solely one that will be solved with more research, data, and reports. In fact, the Homeless Hub, a repository for research on homelessness and related issues in Canada and the United States, contains more than enough evidence to suggest that housing first approaches improve the overall quality of life for homeless and $\mathrm{HtH}$ persons while reducing the expense to society in terms of social services and healthcare (Atherton \& McNaughton Nicholls, 2008; Waegmakers Schiff \& Rook, 2012). Thus, maintaining the status quo is ineffective, costly, and damaging to individuals and communities.

ANSERJ To be notified about new ANSERJ articles, click subscribe / s'inscrire ici. 


\section{Young \& Moses (2013)}

The fundamental question is to what extent we are able to harness the resources available to care for vulnerable populations, for those who temporarily, as is frequently the case, cannot care for themselves. This research has shown that, at the local level, there is a great deal of community concern and energy being devoted to $\mathrm{HtH}$ persons with mental illness and substance abuse problems, but these people have difficulty accessing services when needed. Front-line workers must be supported through increased funding and coordinated efforts on behalf of the business community and local, territorial, and federal governments.

\section{ACKNOWLEDGEMENTS}

The authors would like to thank the service providers and $\mathrm{HtH}$ persons for their participation in this research and HRSDC for funding this project. The comments of two anonymous reviewers are also appreciated.

\section{NOTE}

1. Discussion and analysis of the QoLHHI data will appear in a report submitted to HRSDC and possibly in another article.

\section{REFERENCES}

Abele, F. (2009). The state and the northern social economy: Research prospects. The Northern Review, 30, 37-56.

Abele, F., Falvo, N., \& Hache, A. (2010). Homeless in the homeland: A growing problem for Indigenous people in Canada's North. Parity, 23, 21.

Aboriginal Affairs and Northern Development Canada. (n.d.). Economic and resource development. URL: http://www.aadnc-aandc.gc.ca/eng/1100100022921/1100100022922 [October 21, 2013].

Aboriginal Affairs and Northern Development Canada. (2012). NWT Plain Talk devolution edition. URL:http://www.aadnc-aandc.gc.ca/DAM/DAM-INTER-NWT/STAGING/texte-text/ptdevo12_1345069 989477_eng.pdf [August, 28, 2013].

Aguirre, A., Eick, V., \& Ellen, R. (2006). Introduction: Neoliberal globalization, urban privatization, and resistance. Social Justice, 33, 1-5.

Atherton, I., \& McNaughton Nicholls, C. (2008). "Housing first" as a means of addressing multiple needs and homelessness. European Journal of Homelessness, 2, 289-293.

Beaufort-Delta Health and Social Services. (n.d.). URL: http://bdhssa.nt.ca/community-services linuvik/index.html [August 29, 2013].

Bell, L. (2013). Diamonds as development: Suffering for opportunity in the Canadian North. Unpublished dissertation.

Canadian Mental Health Association. (n.d.). Pathways into and out of homelessness in small B.C. communities. URL: http://www.cmha.bc.ca/files/Pathways_Homelessness.pdf [28 July 28, 2013]. 


\section{Young \& Moses (2013)}

Caragata, L. (2006). Housing and homelessness. In A. Westhues (Ed.), Canadian social policy: Issues and perspectives (4th ed.) (pp. 267-290). Waterloo, ON: Wilfred Laurier University Press.

Christensen, J. (2011). Homeless in a homeland: Homelessness and housing (in)security in Inuvik and Yellowknife, Northwest Territories. PhD dissertation. Montreal, QC: McGill University.

Christensen, J. (2012). "They want a different life": Rural northern settlement dynamics and pathways to homelessness in Yellowknife and Inuvik, Northwest Territories. The Canadian Geographer / Le Géographe Canadien, 56, 419-438.

Citystats. (2009). Inuvik Northwest Territories. URL: http://www.citystats.ca/city/Northwest-Territories/lnuvik.html [July 21, 2013].

Cloke, P., Milbourne, P., \& Widdowfield, R. (2000). Homelessness and rurality: 'Out-of-place' in purified space? Environment and Planning, 18, 715-736.

Covington, S. (1994). Who governs the non-profit sector? Fund Raising Management, 25, 33-36.

Creswell, M. (2006). Designing and conducting mixed methods research. Thousand Oaks, CA: Sage.

Echenberg, H., \& Jensen, H. (2008, December). Defining and enumerating homelessness in Canada. Publication No. PRB 08-30E 29, Social Affairs Division Parliamentary Information and Research Service. URL: http://www.parl.gc.ca/content/lop/researchpublications/prb0830-e.htm\#fn8 [May 30, 2012].

Employment and Development Services Canada. (2013). Homelessness strategy. URL: http://www.hrsdc.gc.ca/eng/communities/homelessness/index.shtml [July 20, 2013].

Enjolras, B. (2000). Coordination failure, property rights and non-profit organizations. Annals of Public and Cooperative Economics, 71, 347-374.

First Nations Information Governance Committee. (2006). Report on First Nations' housing. URL: http://fnigc.ca/sites/defaultffiles/ENpdf/RHS_2002/rhs2002-03-report_on_first_nations_housing.pdf [August 27, 2013].

Gerhardt, H., Steinberg, P.E., Tasch, J., Fabiano, J., \& Shields, R. (2010). Contested sovereignty in a changing Arctic. Annals of the Association of American Geography, 100, 992-1002.

Hackworth, J., \& Moriah, A. (2006). Neoliberalism, contingency and urban policy: The case of social housing in Ontario. International Journal of Urban and Regional Research, 30, 510-527.

Hall, M.H., \& Reed, P.B. (1998). Shifting the burden: How much can government download to the non-profit sector? Canadian Public Administration, 41, 1-20.

Harvey, D. (2005). A brief history of neoliberalism. New York: Oxford University Press.

Hubley, A.M., Russell, L.B., Gadermann, A.M., \& Palepu. A. (2009). Quality of life for homeless and hard-tohouse individuals (QoLHHI) inventory: Administration and scoring manual. Vancouver, BC.

ANSERJ To be notified about new ANSERJ articles, click subscribe / s'inscrire ici. 


\section{Young \& Moses (2013)}

Inuvik Interagency Committee. (2003). Inuvik: Homelessness report. Inuvik, NWT: Inuvik Interagency Committee.

Inuvik Interagency Committee. (2006a). Community wellness in Inuvik, NWT: Summary of issues. Inuvik, NWT: Inuvik Interagency Committee.

Inuvik Interagency Committee. (2006b). Homelessness: State of response in Inuvik, NWT. Inuvik, NWT: Inuvik Interagency Committee.

Kelly, J.G., Mock, L.O., \& Tandon, D.S. (2001). Collaborative inquiry with African-American community leaders: Comments on a participatory action research process. In P. Reason \& H. Bradbury (Eds.), Handbook of action research (pp. 348-355). London, UK: Sage.

Kronstal, A. (2010). Negotiating change: Community mental health and addiction practice in the Northwest Territories of Canada. Unpublished master's thesis. University of Victoria, Victoria, BC.

Laird, G. (2007). Shelter-homelessness in a growth economy: Canada's 21st century paradox. URL: http://www.chumirethicsfoundation.ca/files/pdf/SHELTER.pdf [July 20, 2013].

McBride, S., \& McNutt, K. (2007). Devolution and neoliberalism in the Canadian welfare state: Ideology, national and international conditioning frameworks and policy change in British Columbia. Global Social Policy, 7, 177-201.

Menzies, P. (2009). Homeless Aboriginal men: Effects of intergenerational trauma. In J. D. Hulchanski, P. Campsie, S. Chau, S. Hwang, \& E. Paradis (Eds.). Finding home: Policy options for addressing homelessness in Canada. Toronto, ON: Cities Centre, University of Toronto. URL: http://www.homelesshub.ca/Resource Files/Documents/6.2\%20Menzies\%20-\%20Homeless\%20 Aboriginal\%20Men.pdf [August 18, 2011].

Morgan, N. (2010/11, Winter). Out of place: A rural perspective on housing barriers. Crosscurrents: The Journal of Addiction and Mental Health, 14(2). URL: http://www.camhcrosscurrents.net/archives/ winter2010/out_place.html [August 27, 2013].

National Aboriginal Health Organization. (2005). Ownership, control, access, and possession (OCAP) or selfdetermination applied to research: A critical analysis of contemporary First Nations research and some options for First Nations communities. Ottawa, ON: First Nations Centre.

Northwest Territories Bureau of Statistics. (2010). 2009 NWT community survey. Yellowknife, NWT: Government of the Northwest Territories.

Northwest Territories Housing Corporation. (n.d.). New public housing rent scale. URL: http://nwthc.gov.nt.ca/_live/pages/wpPages/NewRentScale12.aspx [October 6, 2013].

O'Leary, Z. (2004). The essential guide to doing research. Thousand Oaks, CA: Sage.

Pain, R. (2003). Social geography: On action-orientated research. Progress in Human Geography, 27, 649-658.

Peck, J., \& Tickell, A. (2003). Neoliberalizing space: The free economy and the penal state. In Spaces of neoliberalism: Urban restructuring in North America and Western Europe. Maiden, MA: Blackwell Publishers.

ANSERJ To be notified about new ANSERJ articles, click subscribe / s'inscrire ici. 


\section{Young \& Moses (2013)}

Quinn, A. (2007). Reflections on intergenerational trauma: Healing as a critical intervention. First Peoples Family \& Child Review, 3(4), 72-82.

Ryan, J., \& Robinson, M. (1996). Community participatory research: Two views from Arctic Institute practitioners. Practicing Anthropology, 18, 7-11.

Salamon, L.M. (1987). Of market failure, voluntary failure, and third-party government: Toward a theory of government-nonprofit relations in the modern welfare state. Nonprofit and Voluntary Sector Quarterly, 16, 29-49.

Social Planning and Research Council of BC. (2012). Affordable housing for BC's capital region: Tools for the future. URL: http://www.communitycouncil.ca/pdf/CSPC_Report_Tools_for_the_Future_FINAL_NOV15.pdf [October 5, 2013].

Tuhiwai Smith, L. (1999). Decolonizing methodologies: Research and Indigenous peoples. London, UK: Zed Books.

Waegmakers Schiff, J., \& Rook, J. (2012). Housing first: Where's the evidence? The Homeless Hub Paper Series \#1. URL: http://www.homelesshub.ca/library/housing-first---where-is-the-evidence-54120.aspx [July 21, 2013].

Wenzel, G. (1991). Animal rights, human rights: Ecology, economy and ideology in the Canadian Arctic. Toronto, ON: University of Toronto Press.

Wenzel, G. (2008). Clyde Inuit settlement and community: From before Boas to centralization. Arctic Anthropology, 45, 1-21.

Wilson, J. (2009). Poverty reduction, policies and programs: Northwest Territories. Social Development Report Series. Kanata, ON: Canadian Council on Social Development.

Yellowknife Homeless Coalition. (2007). Planning for phase III of the community plan to address homelessness in Yellowknife. Yellowknife, NWT: Yellowknife Homelessness Coalition.

\section{ABOUT THE AUTHORS / LES AUTEURS}

Michael G. Young is Associate Professor in the BA in Justice Studies program with the School of Humanitarian Studies, Royal Roads University, Victoria, BC, Canada. Email: michael.young@royalroads.ca .

Joshua M. Moses is Visiting Assistant Professor with the Department of Anthropology at Haverford College, Haverford, PA, U.S. Email: jmoses@haverford.edu . 